Universidad de Lima

Facultad de Derecho

Carrera de Derecho

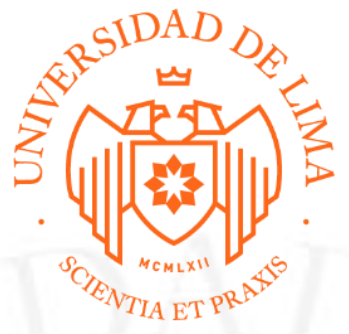

\title{
CIVIL: "RESTITUCIÓN INTERNACIONAL DE MENORES" Y ADMINISTRATIVO: "PROTECCIÓN AL CONSUMIDOR"
}

Trabajo de suficiencia profesional para optar el Título Profesional de Abogada

\section{Carolina Elizabeth Reyna Flores}

Código 20111045

Lima - Perú

Agosto de 2019 


\section{CIVIL: "RESTITUCIÓN INTERNACIONAL DE MENORES"}

Materia: Restitución Internacional de Menor

No de Expediente: 16442-2011-0-1801-JR-FC-16

\section{RESUMEN}

El proceso sujeto a análisis versa sobre el Derecho de Familia y Derecho de Niño, Niña y Adolescente. En este proceso se analizará la correcta aplicación del Convenio de la Haya sobre los Aspectos Civiles de Restitución Internacional de Menores de 1980; en cuanto se determinará si la menor fue trasladada de manera ilícita de su residencia habitual.

PENAL: ADMINISTRATIVO: "PROTECCIÓN AL CONSUMIDOR"

Materia: Protección al Consumidor

$\mathrm{N}^{\mathrm{o}}$ de Expediente: 00 0149-2013/CPC

\section{RESUMEN}

El procedimiento sujeto a análisis versa sobre el Derecho de Protección al Consumidor. En este procedimiento se analizará la correcta aplicación de Código de Protección y Defensa del Consumidor; en cuanto se determinará si el denunciado cometió una infracción al deber de idoneidad, estipulado en los artículos $18^{\circ}$ y $19^{\circ}$ del mismo. 